\title{
技術論文
}

\section{ピペットチップ型固相抽出を用いる清涼飲料水等に混入された パラコート及びジクワットの簡易定性試験法}

\author{
鈴木 雄亮 ${ }^{1}$, 金子 毅 $^{\circledR 1}$
}

\begin{abstract}
清涼飲料水中に混入されたパラコート（PQ）及びジクワット（DQ）の迅速・簡便な定性試験法を検討し た. 抽出にはピペットチップ型固相抽出デバイスである OMIX ${ }^{\circledR}$ pipette tip を用いた. コーラ及びコーヒー飲 料に $\mathrm{PQ}$ 及び DQを添加した試料について，C18，C4 及び SCX タイプの OMIX ${ }^{\oplus}$ pipette tip により抽出を行 った. $\mathrm{C} 18$ 及び $\mathrm{C} 4$ タイプのものを用いて抽出された $\mathrm{PQ}$ 及び $\mathrm{DQ}$ は，呈色試験及び液体クロマトグラフィ 一/質量分析（LC/MS）により同定された。抽出に要した時間は，1 検体あたり 3 分程度であった. SCX 夕 イプのものを用いた場合は，PQ及び $\mathrm{DQ}$ の回収に飽和食塩水を用いるため，LC/MS には不向きであるが, 呈色反応による検出は可能であり，また，抽出操作も $\mathrm{C} 18$ 及び $\mathrm{C} 4$ の場合と比較してより簡便であることか ら呈色試験によるスクリーニングには, 非常に有用であると考えられた.
\end{abstract}

\section{1 緒言}

アルキルジピリジリウム塩系農薬は, 非ホルモン型の非 選択性茎葉処理除草剤であり，代表的なものとしてパラコ ート, ジクワットがある。「毒物及び劇物取締法」では, パ ラコートは毒物に, ジクワットは劇物に指定されている. これらの製品による自殺は 1980 年代に比べ大幅に減少し ているものの後を絶たない．また，清涼飲料水などに混入 し，これを喫食させることによる無差別又は特定の個人を 標的とした殺人又は傷害事件もまれに発生している.

このため,これにかかわる証拪物件が鑑定資料として科 学捜查研究所に持ち込まれ, 分析する機会がある。これら の成分に対する定性試験は亜ジチオン酸ナトリウム（ハイ ドロサルファイトナトリウム)による呈色試験 ${ }^{1)}$ ，ガスク ロマトグラフィー/質量分析法 ${ }^{23)}$, 液体クロマトグラフィ 一/質量分析法 ${ }^{4)}$ (7) (LC/MS), キャピラリー電気泳動法 ${ }^{899}$ などを行うものであるが，これらの試験は，事故防止のた めに製剂に添加されている催吐剤や青色色素など, 試料の マトリックス成分が妨害となるため, 前処理を施し莝雑物 を取り除いた後，行わなければならない．これまでに前処 理方法として逆相系の固相抽出カートリッジを用いた方 法 $^{10) 11}$ が知られているが, 試料の $\mathrm{pH}$ の調整や溶出後の濃 縮など, 操作が煩雑である.

最近, マイクロピペッター用のチップ先端に固相充填剤 を取り付けたものが市販されている。 これは，固相のコン ディショニングから保持した物質の溶出までの一連の操作

\footnotetext{
${ }^{1}$ 千葉県警察本部科学捜查研究所：260-0024 千葉県千葉市中央 区中央港 1-71-1
}

をマイクロピペッターに装着した状態のままで行うことが 可能な固相抽出デバイスであり, 従来のカートリッジタイ プの固相抽出デバイスと比較して操作が簡便で, 必要な試 料量も極少量（50～100 $\mu \mathrm{L}$ 程度）でよいなどの利点があ る.このデバイスによる抽出手法 (micro volume solid phase

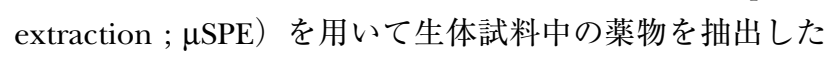
例があり $\left.{ }^{12)} 15\right)$, 飲食物からの薬毒物の抽出にも応用でき る可能性がある.

そこで, 本研究では, ピペットチップ型固相抽出デバイ スによる飲料中に混入されたパラコート及びジクワットの 前処理方法について検討し, 後に続く呈色試験及び LC/ MS と合わせた簡易定性試験法の確立を目的とした。

$$
2 \text { 実験 }
$$

\section{$2 \cdot 1$ 試 薬}

パラコート（PQ） ジクロリド及びジクワット（DQ） ジ ブロミド水和物はいずれも Dr. Ehrenstorfer $\mathrm{GmbH}$ 製のも のを用いた。これらの混合製剂であるシンジェンタ製の除 草剤プリグロックス L （パラコートジクロリド $5 \%$ 含有, ジクワットジブロミド $7 \%$ 含有）をコーラ及びコーヒー飲

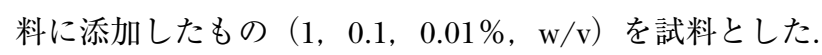
メタノールは関東化学製の電子工業用のものを, キ酸は和 光純薬製の LC/MS グレードのものを用いた，その他の試 薬は, 市販の特級試薬をそのまま使用した。

\section{$2 \cdot 2$ マイクロ固相抽出 $(\mu \mathrm{SPE})$}

マイクロ固相抽出 $(\mu \mathrm{SPE})$ は, 固相抽出ピペットチップ である VARIAN 製の $\mathrm{C} 18, \mathrm{C} 4$ 及び SCX タイプの $\mathrm{OMIX}^{\circledR}$ 
Pipette Tips をマイクロピペッターに取り付けて行った. C18 及び C4 タイプは，モノリスシリカにそれぞれオク夕 デシル基及びブチル基を化学結合した充填剤を用いたもの であり，主に無極性相互作用により有機化合物が保持され る. 一方, SCX タイプは, ベンゼンスルホン酸を化学結合 した充填剂を用いており, 強カチオン交換作用により, カ チオン状態の有機化合物が保持される．Fig. 1 に本実験に 使用した固相抽出用ピペットチップを示す.

いずれのタイプの固相抽出ピペットチップも，固定相の 充填された部位にメタノール $200 \mu \mathrm{L}$ を 1 回通した後, 蒸留 水 $200 \mu \mathrm{L}$ を 1 回通してコンディショニングし, その後の抽 出操作に用いた.

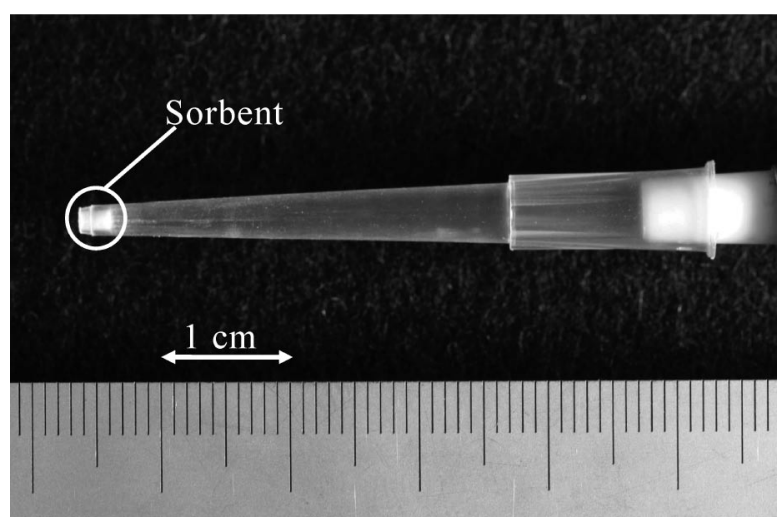

Fig. 1 Micropipette tip type solid phase extraction device
2・2・1 C18 及び C4 タイプによる $\mu \mathrm{SPE}$ 抽出の手順 は Fig. 2 に示すとおりに行った. 固相抽出ピペットチップ をマイクロピペッターに取り付け，コンディショニングし た後, 希釈した製剤添加試料 $200 \mu \mathrm{L}$ 製剤添加試料 $100 \mu \mathrm{L}$ を $0.5 \mathrm{M}$ 炭酸水素ナトリウム/炭酸ナトリウム緩衝液 $(\mathrm{pH}$ 10） $100 \mu \mathrm{L}$ で希釈したもの\} が入ったバイアル中で吸引・ 吐出操作を 5 回繰り返すことにより, $\mathrm{PQ}$ 及び $\mathrm{DQ}$ を固相 抽出ピペットチップに保持した. 次に, 蒸留水 $200 \mu \mathrm{L}$ を 2 回，メタノール $200 \mu \mathrm{L}$ を 2 回通液することによるクリーン アップを行った後, $5 \mathrm{mM}$ ギ酸/ギ酸アンモニウム緩衝液 (pH 3.5) $100 \mu \mathrm{L}$ 中で吸引・吐出を 5 回繰り返し, PQ及び DQの回収を行った。これを呈色試験及び LC/MS 測定用 試料とした.

2・2・2 SCX タイプによる $\mu \mathrm{SPE} \quad$ 製剤添加試料 $200 \mu \mathrm{L}$ について, 前記 $2 \cdot 2 \cdot 1$ と同様の手順により, 固相抽出用ピ ペットチップヘの $\mathrm{PQ}$ と $\mathrm{DQ}$ の保持及びピペットチップの 洗浄を行った. 回収は $0.2 \mathrm{M}$ ギ酸アンモニウム緩衝液 $(\mathrm{pH}$ 3.5） $100 \mu \mathrm{L}$ で行った.

\section{$2 \cdot 3$ 呈色試験}

前記 $2 \cdot 2 \cdot 1$ 及び $2 \cdot 2 \cdot 2$ の項で得られた抽出液 $50 \mu \mathrm{L}$ を白 色呈色板上にとり， $1 \mathrm{M}$ 水酸化ナトリウム水溶液 $10 \mu \mathrm{L}$ 及 びハイドロサルファイトナトリウム約 $10 \mathrm{mg}$ を添加し, 污 青〜污青緑色の呈色を確認した.

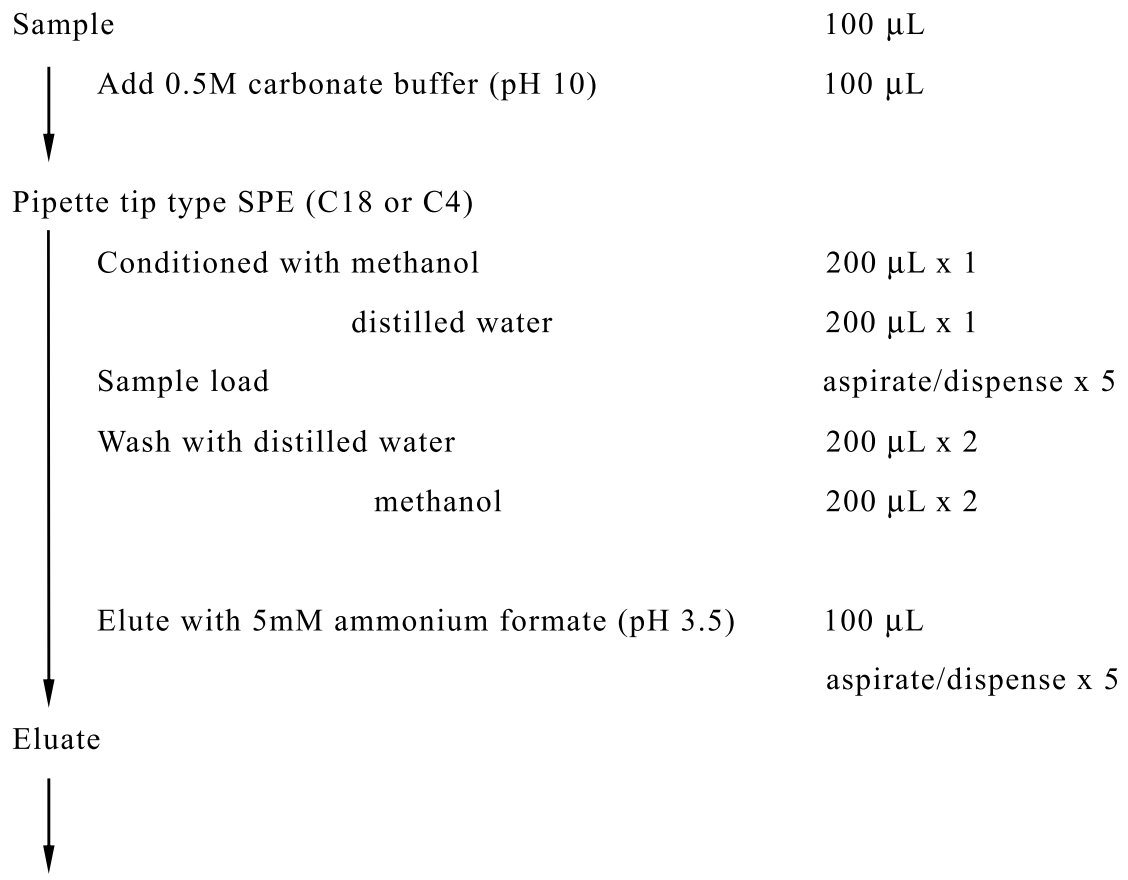

Color test and LC-MS

Fig. 2 Extraction procedure with OMIX ${ }^{\circledR}$ pipette tips (C18 or C4 type) 

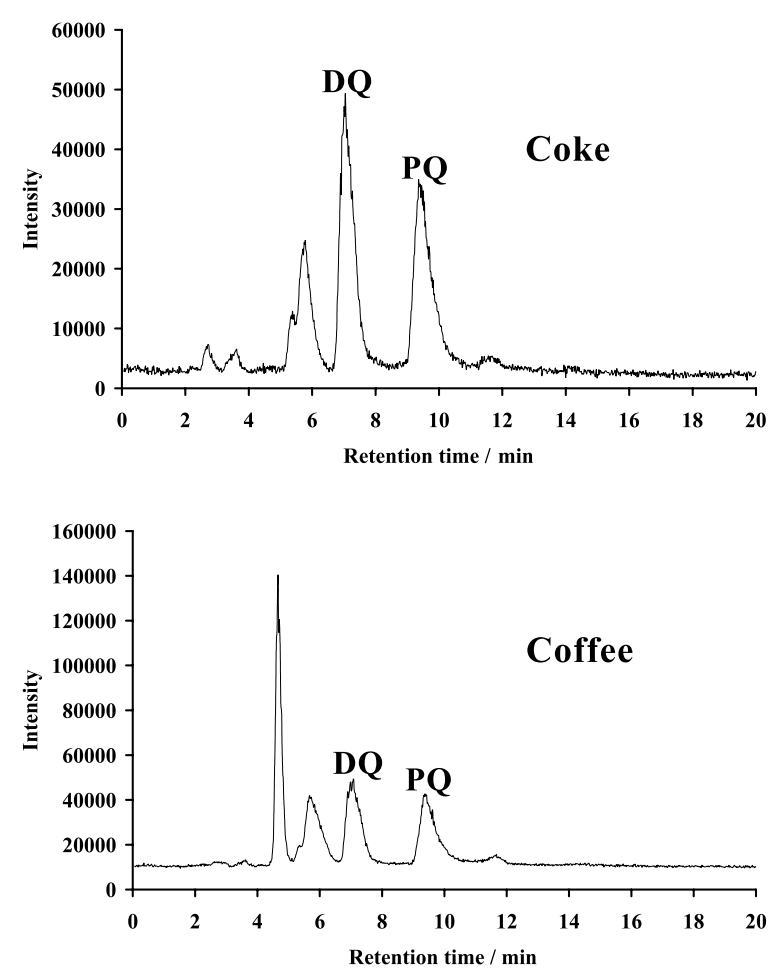

Fig. 3 Total ion chromatograms of extracts from spiked sample (Preeglox-L ${ }^{\circledR}, 0.01 \%, \mathrm{w} / \mathrm{v}$ ) by C4-type OMIX $^{\circledR}$ pipette tip (top; coke, bottom; coffee)

\section{$\mathbf{2 \cdot 4}$ 液体クロマトグラフィー質量分析（LC/MS）}

マイクロ固相抽出により抽出された $\mathrm{PQ}$ 及び $\mathrm{DQ}$ の測定 は LC/MSにより行った. 装置は Waters 製の alliance ZMD を, 分離カラムとして SUPELCO 製の HS- F5（150 mm × $2.1 \mathrm{~mm}$ i.d., 粒子径 $5 \mu \mathrm{m}$ ）を用いて行った。溶離液は $5 \mathrm{mM}$ ギ酸/ギ酸アンモニウム緩衝液 ( $\mathrm{pH}$ 3.5) とメタノー ルの混合液 $(94+6$ 容量 $)$ を用い, 流量は $0.2 \mathrm{~mL} \mathrm{~min}^{-1}$ と した. 試料はオートサンプラーを用いて $10 \mu \mathrm{L}$ を注入した. 紫外線 (UV) 検出波長は $258 \mathrm{~nm}(\mathrm{PQ})$ 及び $309 \mathrm{~nm}(\mathrm{DQ})$ とした．質量分析の条件は，ポジティブモードのエレクト ロスプレーイオン化法, コーン電圧 $20 \mathrm{~V}$, キャピラリー電 圧 $3 \mathrm{kV}$, ソースブロック温度 $100^{\circ} \mathrm{C}$, 脱溶媒温度 $400^{\circ} \mathrm{C}$, 脱 溶媒ガスとして窒素を $400 \mathrm{~L} \mathrm{~h}^{-1}$ に設定し, $m / z 100$ から 250 までのスキャンモードにより測定を行った.

\section{3 結果及び考察}

$3 \cdot 1 \mathrm{C4}$ 及び C18 タイプ固相抽出による製剤添加試料 からの $\mathbf{P Q}$ 及び $\mathbf{D Q}$ の回収

$\mathrm{C} 4$ 及び C18 タイプを用いて，製剤添加試料から得られ た抽出液について, 呈色試験を行ったところ, C4を用いた 場合は, いずれの試料（製剂添加濃度 $1 \%, 0.1 \%$ 及び $0.01 \% ）$ から得られた抽出液も呈色の確認が可能であっ た. C18 を用いた場合は, 製剂添加濃度 $1 \%$ 及び $0.1 \%$ の 試料については, 呈色の確認が可能であったが, 製剤添加

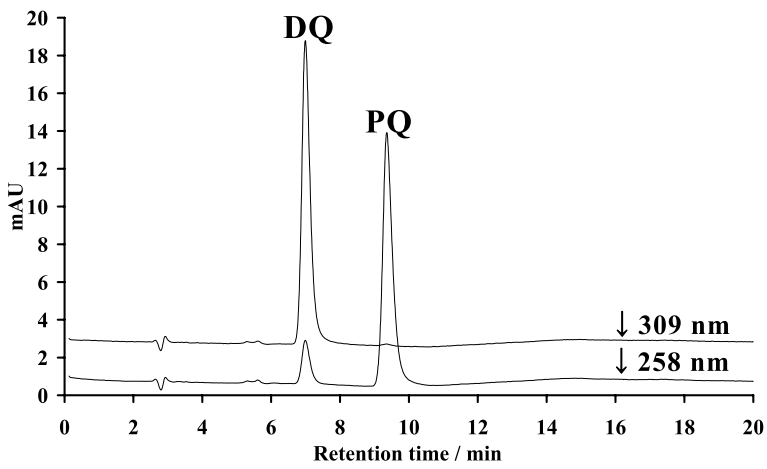

Fig. 4 UV chromatograms of extract from spiked coke (Preeglox-L ${ }^{\circledR}, 0.01 \%, \mathrm{w} / \mathrm{v}$ ) by C4-type OMIX ${ }^{\circledR}$ pipette tip

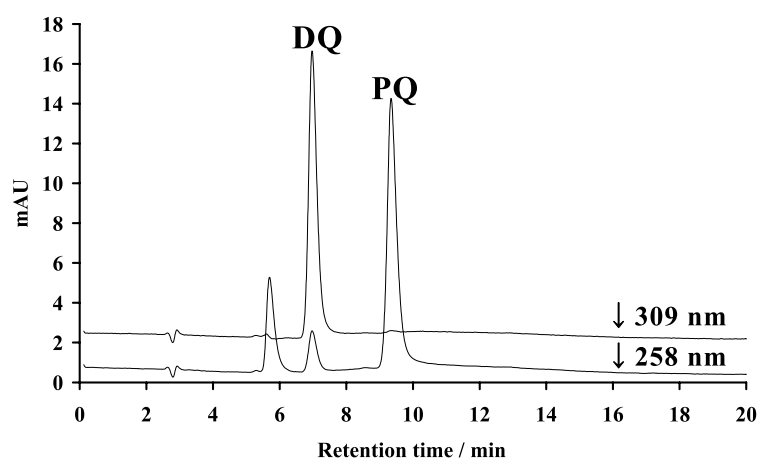

Fig. 5 UV chromatograms of extract from spiked coffee $\left(\right.$ Preeglox-L $\left.{ }^{\circledast}, 0.01 \%, w / v\right)$ by C4-type OMIX ${ }^{\circledR}$ pipette tip

濃度 $0.01 \%$ の試料については, 呈色しなかった.

C4 及び C18 タイプにより得られた抽出液の一部につい て, LC/MS 測定を行ったところ, $\mathrm{PQ}$ 及び DQは良好に分 離し, 妨害ピークは認められず, マススペクトルも各標準 品とほぼ一致した，UVによる検出においても，妨害ピー クは認められなかった. C4 タイプを用いて, 試料（添加濃 度 $0.01 \%$ ）から得られた抽出液のトータルイオンクロマト グラムを Fig. 3に, UVクロマトグラムを Fig. 4及び Fig. 5 に示す.

$\mathrm{PQ}$ 及び DQの濃度が各 $2 \mu \mathrm{g} \mathrm{mL} \mathrm{mL}^{-1}$ となるように標準水 溶液を添加したコーラ及びコーヒー飲料を用いて, 回収率 を求めたところ，C4タイプを用いた場合で，いずれも $30 \%$ 前後であった．C18 タイプを用いた場合は，20〜 25\%で あった。

試料の希釈に $0.1 \mathrm{M}$ 又は $1 \mathrm{M}$ 炭酸水素ナトリウム/炭酸 ナトリウム緩衝液（pH 10）を用い, 初期条件（0.5 M 炭酸 水素ナトリウム/炭酸ナトリウム緩衝液）で抽出した際の 回収率を基準として比較したところ，0.1 M 炭酸水素ナト リウム/炭酸ナトリウム緩衝液を用いた場合が最も回収率 


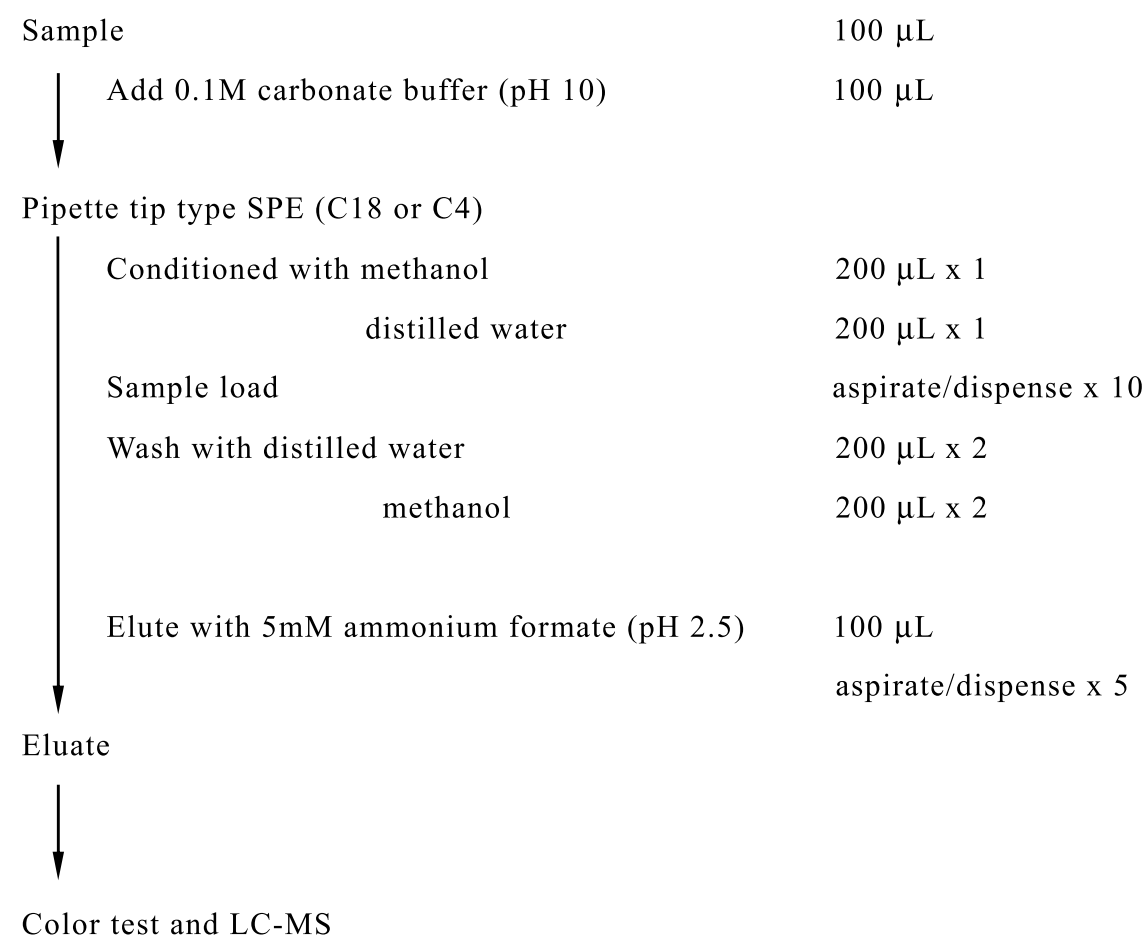

Fig. 6 Improved extraction procedure with $\mathrm{OMIX}^{\circledR}$ pipette tips (C18 or C4 type)

Table 1 Recovery of PQ and DQ from coke and coffee by OMIX ${ }^{\circledR}$ (C4 and C18)

\begin{tabular}{cccc}
\hline \multirow{2}{*}{ Sample } & Sorbent type & \multicolumn{3}{c}{ Recovery, \% } \\
& & PQ & DQ \\
\hline \multirow{2}{*}{ Coke } & C4 & $48.7(1.1)$ & $57.2(1.6)$ \\
& C18 & $50.1(1.2)$ & $53.0(1.5)$ \\
Coffee & C4 & $55.1(1.7)$ & $60.8(1.8)$ \\
& C18 & $55.9(1.6)$ & $57.5(1.1)$ \\
\hline
\end{tabular}

Coke and coffee were spiked with $\mathrm{PQ}$ and $\mathrm{DQ}$ at a concentration of $2 \mu \mathrm{g} \mathrm{mL}^{-1}$ respectively. The values (\%) represent the mean and $( \pm$ S.D. $)$ of five determinations.

が高く, PQについては約 1.2 倍, DQについては約 1.4 倍 であった. $1 \mathrm{M}$ 炭酸水素ナトリウム/炭酸ナトリウム緩衝液 を用いた場合は回収率は低下し, PQについては基準の約 7 割, DQについては約 6 割にとどまった.このことから,ア

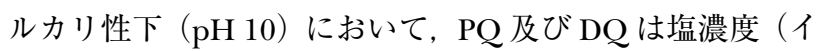
オン強度）が低いほど保持されやすくなることが分かっ た.

次に, 成分を保持する際の吸引・吐出の回数を 10 回, 20 回及び 30 回とし, 初期条件（5 回）での回収率を基準とし て比較したところ, 20 回及び 30 回の場合が最も回収率が 高く, PQについては約 1.4 倍, DQについては約 1.2 倍で あったが, 抽出時間の短縮を考慮すると, 回収率は若干低 下する (PQ; 約 1.2 倍, DQ; 約 1.1 倍) が, 10 回が適当で あると判断した.
次に，保持した成分を回収する際に用いる $5 \mathrm{mM}$ ギ酸/ ギ酸アンモニウム緩衝液の $\mathrm{pH}$ を $3 ， 2.5 ， 2$ とし，初期条 件（pH 3.5）での回収率を基準として比較したところ, $\mathrm{pH}$ 2.5 及び $\mathrm{pH} 2$ とした場合が最も回収率が高く, PQ及び $\mathrm{DQ}$ いずれも約 1.2 倍であった. $\mathrm{pH} 2$ の緩衝液を用いて得られ た抽出液について LC/MS 測定を行ったところ，移動相の $\mathrm{pH}$ （3.5）との差に起因すると考えられるピークのテーリ ング現象が認められたことから，回収に用いる緩衝液の $\mathrm{pH}$ は 2.5 が最適であると判断した.

上記の結果を総合し，改良した抽出方法を Fig. 6 に示 す．この方法を用いて，PQ及び $\mathrm{DQ}$ の回収率を求めたと ころ，改良前は $20 〜 30 \%$ 前後であった回収率が，50〜 $60 \%$ 程度に改善された（Table 1)。また，抽出にかかる時 間は試料 1 検体当たり 3 分程度であった．本法における回 収率 $(50 \sim 60 \%)$ は, 従来の固相抽出カートリッジを用い た場合 ${ }^{10) 11}$ の回収率 $(\mathrm{PQ} ;>95 \%, \mathrm{DQ} ;>97 \%)$ と比較す ると低いものであった。これは，抽出に用いた固相抽出ピ ペットチップの充填剤の量が $2.4 \mathrm{mg}$ と, カートリッジタイ プの数十分の一から数百分の一程度であることから，一定 量の充填戍に対する清涼飲料水由来の夾雑成分の存在量が 大きくなってしまい，保持のステップにおいて夾雑成分と $\mathrm{PQ}$ 及び $\mathrm{DQ}$ の競合が起こるためであると考えられた.

本法は，従来法と比較すると回収率が低い（50〜 $60 \%)$ が，通常，毒物混入事件に扔ける混入成分の濃度は，高濃 度（>数\%）であることが多いことから，十分に実務に耐 えうるものであると思われる．また，一連の抽出操作をマ 
イクロピペッターに装着したまま行うことができること， 抽出に必要な試薬類の量が従来法の 10 分の 1 以下である こと, 試料 1 検体当たりの抽出にかかる時間が 3 分程度で あり短時間で多検体を処理することが可能であることか ら，実務上，非常に有用であると考えられた.

\section{$3 \cdot 2 \mathrm{SCX}$ タイプ固相抽出による製剤添加試料からの}

\section{PQ 及び DQ の回収}

SCX タイプを用いて, 製剤添加試料から得られた抽出液 について, 呈色試験を行ったところ, 製剤添加濃度 $1 \%$ 及 び $0.1 \%$ の試料については, 呈色の確認が可能であったが, 製剂添加濃度 $0.01 \%$ の試料については，呈色しなかった。

SCX タイプにより得られた抽出液の一部について, LC/ MS を行ったところ, 数分間にわたるブロードなピークが 検出され，同定が困難であった。これは抽出液と移動相の 塩濃度の差が原因であると考えられたため, 抽出液を蒸留 水で 10 倍に希釈したところ, $\mathrm{PQ}$ 及び DQはそれぞれ独立 したピークとして良好に分離し，マススペクトルにより同 定が可能となった. しかし， $\mathrm{PQ}$ 及び $\mathrm{DQ}$ の含有量が少な い試料の場合は, 抽出液を希釈することで $\mathrm{PQ}$ 及び $\mathrm{DQ}$ の 濃度が検出下限以下となってしまい, その結果, 見落とし てしまう可能性も無視できない. そこで, 呈色試験のみに 目的を絞り, 更に塩濃度の高い飽和食塩水を溶出液として 用いたところ, 製剤添加濃度 $0.01 \%$ の試料についても呈色 が確認できた。試料の $\mathrm{pH}$ 調整が不要であり, 準備するも のも水, メタノール, 飽和食塩水だけでよいことから, 呈 色試験によるスクリーニングだけを行う場合であれば, SCX タイプを用いる方法は有用であると考えられた.

溶出液として飽和食塩水を用いた場合は, LC/MS 測定 を行う際に水で数百倍に希釈する必要があり, その結果, 溶出液中の $\mathrm{PQ}$ 及び $\mathrm{DQ}$ の濃度が検出限界以下となり, ピ ークとして検出することが困難であったため, 回収率は求 めることができなかった.

\section{4 結 論}

ピペットチップ型固相抽出デバイスである $\mathrm{OMIX}^{\circledR}$ pipette tipにより, 清涼飲料水中（コーラ及びコーヒー飲 料)に混入されたパラコート及びジクワットは, C4 タイプ で 48\% 以上, C18 タイプで 50\% 以上の回収率が認められ た. 本法を用いることにより, 試料量 $100 \mu \mathrm{L}$ の製剂添加濃 度 $0.01 \%$ の試料 $\left(\mathrm{PQ} ; 3.6 \mu \mathrm{g} \mathrm{mL}^{-1}, \mathrm{DQ} ; 3.7 \mu \mathrm{g} \mathrm{mL}^{-1}\right.$ ) ま で呈色試験による確認が可能であり, 抽出されたパラコー ト及びジクワットは LC/MSにより良好に分離・検出する
ことができた.

SCX タイプを用いた場合も, 製剤添加濃度 $0.01 \%$ の試 料（PQ; $3.6 \mu \mathrm{g} \mathrm{mL}^{-1}, \mathrm{DQ} ; 3.7 \mu \mathrm{g} \mathrm{mL}^{-1}$ ) まで呈色の確認 が可能であった．溶出液の塩濃度が高いので, LC/MSには 導入することはできないが，C4 及び C18 タイプを用いた 場合と比較して，より簡便な操作で抽出することが可能で あることから，呈色試験によるスクリーニングのための前 処理方法として非常に有用であるといえる.

試料点数が少ない場合には，抽出物をそのまま LC/MS に導入することができる C18, C4 タイプのものを用いる方 法が有利である．試料点数が多い場合には，試料の $\mathrm{pH}$ 調 整が不要で, より簡便な操作で抽出・スクリーニングがで きるSCXタイプのものを用い, 呈色試験で陽性であった試 料についてのみ C18 又は C4 タイプによる抽出を行い, LC/MS により同定することで効率的な検査が可能になる と考えられた。

\section{文献}

1) 日本薬学会編 : “薬毒物化学試験法と注解 2006”, p. 262 (2006), (東京化学同人).

2) M. A. Rafael, Y. Mauricio : J. Chromatogr. B, 853, 260 (2007).

3) C. P. Norberto, M. O. Enrique, M. B. Dawn : J. Chromatogr. B, 862, 93 (2008).

4) R. Castro, E. Moyano, M. T. Galceran : J. Chromatogr. A, 914, 111 (2001).

5) G. Lorna, M. Bick, Y. Paul : J. Chromatogr. A, 958, 25 (2002).

6) L. Xiao-pen, T. Kumazawa, M. Fujishiro, C. Hasegawa, T. Arinobu, H. Seno, A. Ishii, K. Sato : J. Mass. Spectrom., 39, 1147 (2004).

7) M. A. Marinah, A. Rovert : J. Chromatogr. B, 842, 91 (2006).

8) T. Ishikawa, S. Onuki, H. Okada, K. Ohashi : Jpn. J. Forensic Toxicol., 20, 284 (2002).

9）成田有史，富岡なおこ，飯田英己，柳 幸男，皆川 節：日本法科学技術学会誌, 10,171 (2005).

10) 角田紀子：衛生化学, 29, 206 (1983).

11) 佐藤常寿: 科学警察研究所報告 法科学編, 41, 265 (1988).

12) J. X. Shen, C. I. Tama, R. N. Hayes : J. Chromatogr. B, 843, 275 (2006).

13) T. Kumazawa, C. Hasegawa, L. Xiao-pen, A. Maruno, N. Shimmen, A. Ishii, H. Seno, K. Sato : Talanta, 70, 474 (2006).

14) T. Kumazawa, C. Hasegawa, L. Xiao-pen, K. Hara, H. Seno, O. Suzuki, K. Sato : J. Parm. Biomed. Anal., 44, 602 (2007).

15) 鈴木雄亮, 佐藤雅子，金子 毅：法科学技術, 13, 45 (2008). 


\title{
Rapid and Simple Detection of Paraquat and Diquat in Beverages Using Pipette-Tip Solid-Phase Extraction
}

\author{
Yusuke SuzukI $^{1}$ and Tsuyoshi KanEKo ${ }^{1}$ \\ ${ }^{1}$ Forensic Science Laboratory, Chiba Prefectural Police H.Q., 1-71-1, Chuoko, Chuo-ku, Chiba-shi, Chiba \\ 260-0024
}

(Received 22 July 2009, Accepted 29 September 2009)

\begin{abstract}
A rapid and simple detection for paraquat $(\mathrm{PQ})$ and diquat $(\mathrm{DQ})$ intentionally mixed in beverages was developed. A pipette tip-type micro volume solid-phase extraction device, OMIX ${ }^{\circledR}$ pipette tip (solid-phase type ; C18, C4 and SCX) was used for the extraction of PQ and DQ. The extracted PQ and DQ were successfully detected by a color test and/or liquid chromatography/mass spectrometry (LC/MS). An $100 \mu \mathrm{L}$ volume of a sample (coke or coffee spiked with appropriate amounts of PQ and DQ) was alkalinized by adding $100 \mu \mathrm{L}$ of $0.1 \mathrm{M}$ sodium carbonate buffer ( $\mathrm{pH} \mathrm{10).} \mathrm{Then,} \mathrm{PQ} \mathrm{and} \mathrm{DQ} \mathrm{in} \mathrm{the} \mathrm{mixture} \mathrm{were} \mathrm{retained} \mathrm{onto} \mathrm{the} \mathrm{C} 18$ or $\mathrm{C} 4$ phase of an OMIX ${ }^{\circledR}$ pipette tip by 10-times repeating the aspirate/dispense cycles using a manual micropipettor. After being washed with water and methanol, $\mathrm{PQ}$ and DQ were eluted with 100 $\mu \mathrm{L}$ of $5 \mathrm{mM}$ ammonium formate $(\mathrm{pH} 2.5$ ) by 5-times repeating the aspirate/dispense cycles. It took only 3 minutes for one sample preparation. The color test was carried out by adding an $1 \mathrm{M}$ sodium hydroxide solution and sodium hydrosulfite to half of the extract and the remaining part was subjected to LC/MS analysis. The extracted PQ and DQ were successfully separated and each of the $[\mathrm{M}+\mathrm{H}]^{+}$ions were observed under the optimized LC/MS condition. The extraction procedure using an SCX-type pipette tip was more simple than the other type of solid phase. PQ and DQ were retained to the SCX phase without any adjustment of the $\mathrm{pH}$ and eluted with a saturated aqueous sodium chloride solution. This procedure was suitable for a color test, but not for LC/MS by because of the large amount of sodium chloride in the extract. This method was very useful for suspicious cases of $P Q$ and $D Q$ poisonings in beverages.
\end{abstract}

Keywords : micro volume solid-phase extraction ; paraquat ; diquat. 